\title{
PRODUCTION OF SODIUM SILICATE FROM RICE HUSK ASH WITH REGULATORY SETS MAGNESIUM
}

\author{
${ }^{1}$ Yanatra Budi Pramana, ${ }^{2}$ M. Amin Pahlevi, ${ }^{3}$ Zhulianto Ashari, ${ }^{4}$ M.Fariz Effendi, ${ }^{5}$ Fibra Gilang \\ Ramadhan \\ ${ }^{12345}$ Industrial Engineering Department \\ Faculty of Industrial Technology University of PGRI Adi Buana Surabaya \\ Email : p_yanatra@unipasby.ac.id
}

\begin{abstract}
Utilization of rice husks in Indonesia in general is still very limited. Utilization of silica contained in rice husk ash, which has been used, among others, in the manufacture of sodium silicate. Silica compounds themselves can be used in and manufacturing basic materials for electronic and ceramic equipment, glass, rubber, cosmetic products, and pharmaceuticals. The addition of $\mathrm{Mg}$ can increase the silica content $\left(\mathrm{SiO}_{2}\right)$ in rice husk ash. The best results show an effective $\mathrm{Mg}$ ratio of $\mathrm{Mg}$ addition to increase silica content is 1: 1. produces the highest amount of silica which is $58.12 \%$ of the rice hus ash with a size of 140 mesh.
\end{abstract}

Keywords: rice husk, natrium silica, Magnesium.

\section{INTRODUCTION}

In Indonesia, rice husks produced from milling or pounding of grain are still agricultural waste, which until now has become a problem, besides being only piled up as rubbish, burning husks also results in serious air pollution. Although there are some areas in Indonesia that use rice husk as fuel for both household and brick making and the ashes are used as rubbing ash, the use of rice husk in general is still very limited. World rice husk production currently reaches 80 million tons by weight, this means there is a silica content of about 3.2 million tons in world rice husk (Souza et al., 2000). Previous studies on ash produced from rice husk pyrolysis showed that silica content in ash reached $94.39 \%$ (Erawati, 1994). Utilization of silica contained in rice husk ash, which has been used, among others, in the manufacture of Silicon Nitride powder, Si3N4, which is the result of pyrolysis of husk ash in nitrogen flow. Silicon Tetrachloride, $\mathrm{SiCl}_{4}$, which is the result of chlorination of rice husk ash which has been hydrolyzed in a nitrogen atmosphere. Sodium Silicate $\left(\mathrm{Na}_{2} \mathrm{SiO}_{3}\right)$ which is a compound produced by the reaction of rice husk ash with sodium hydroxide $(\mathrm{NaOH})$ solution (Sitompul et al, 1999). From the various uses of rice husk ash above, it will be very potential and can be an economic advantage if the silica extracted from rice husk is a high quality product, that is if the surface area, particle size and purity factor (Souza et al., 2000). The rice husk used came from the area, Sidoarjo. 


\section{METHODOLOGY}

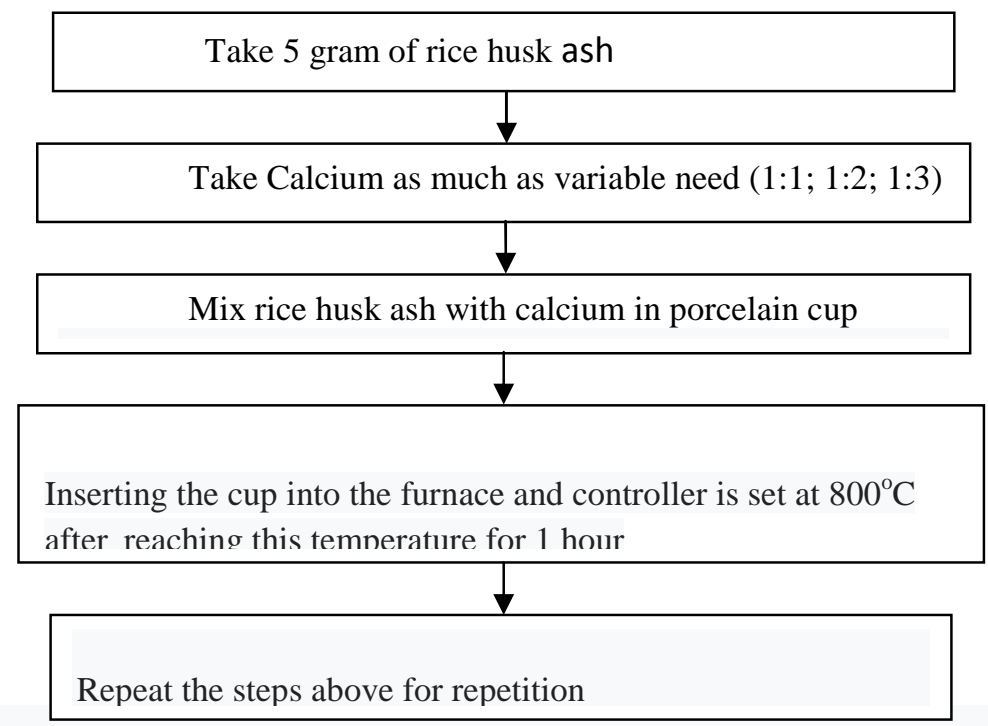

Figure 1. Schematic of the Mg treatment process

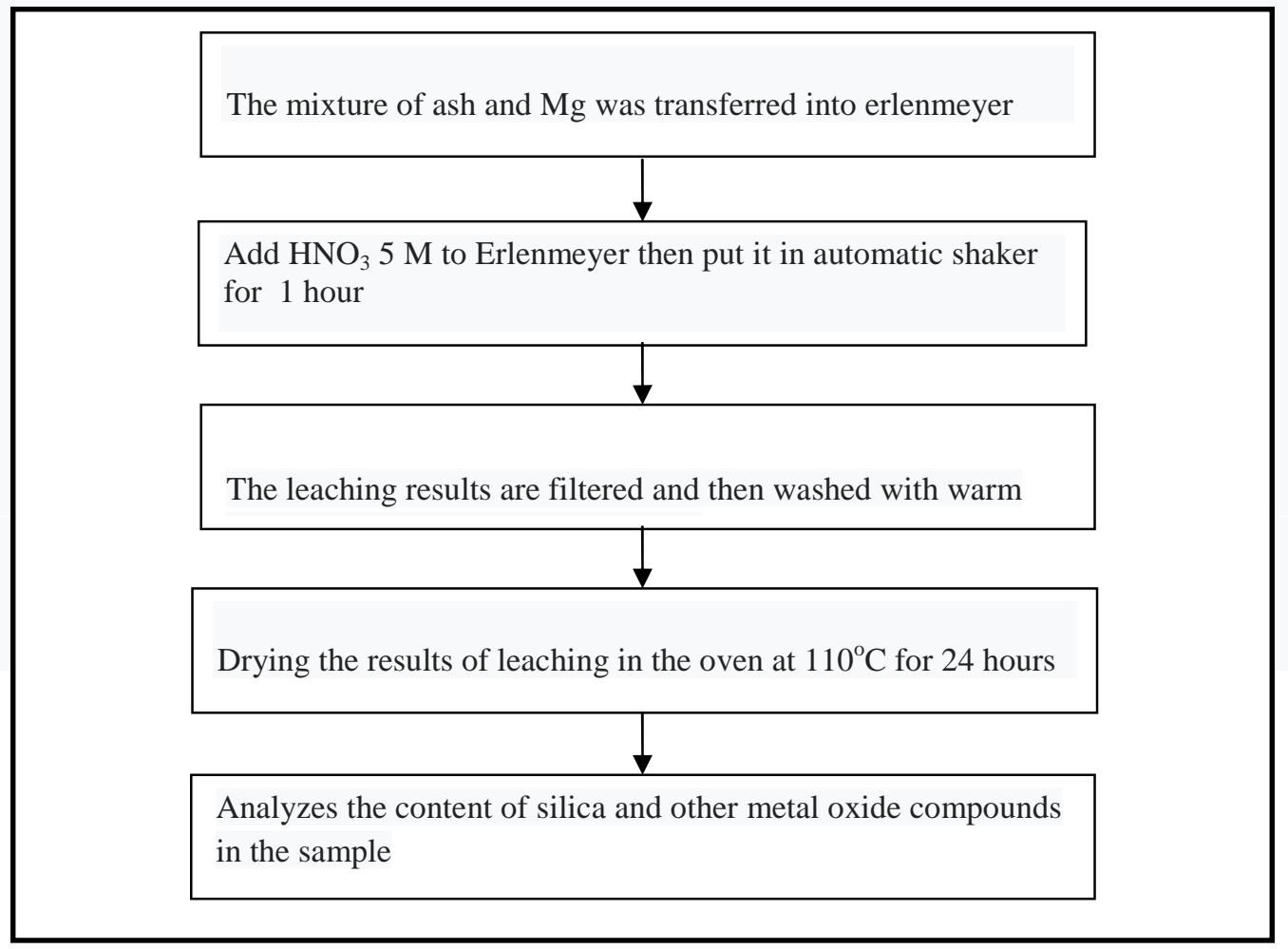

Fig 2. Acid Leaching Process 


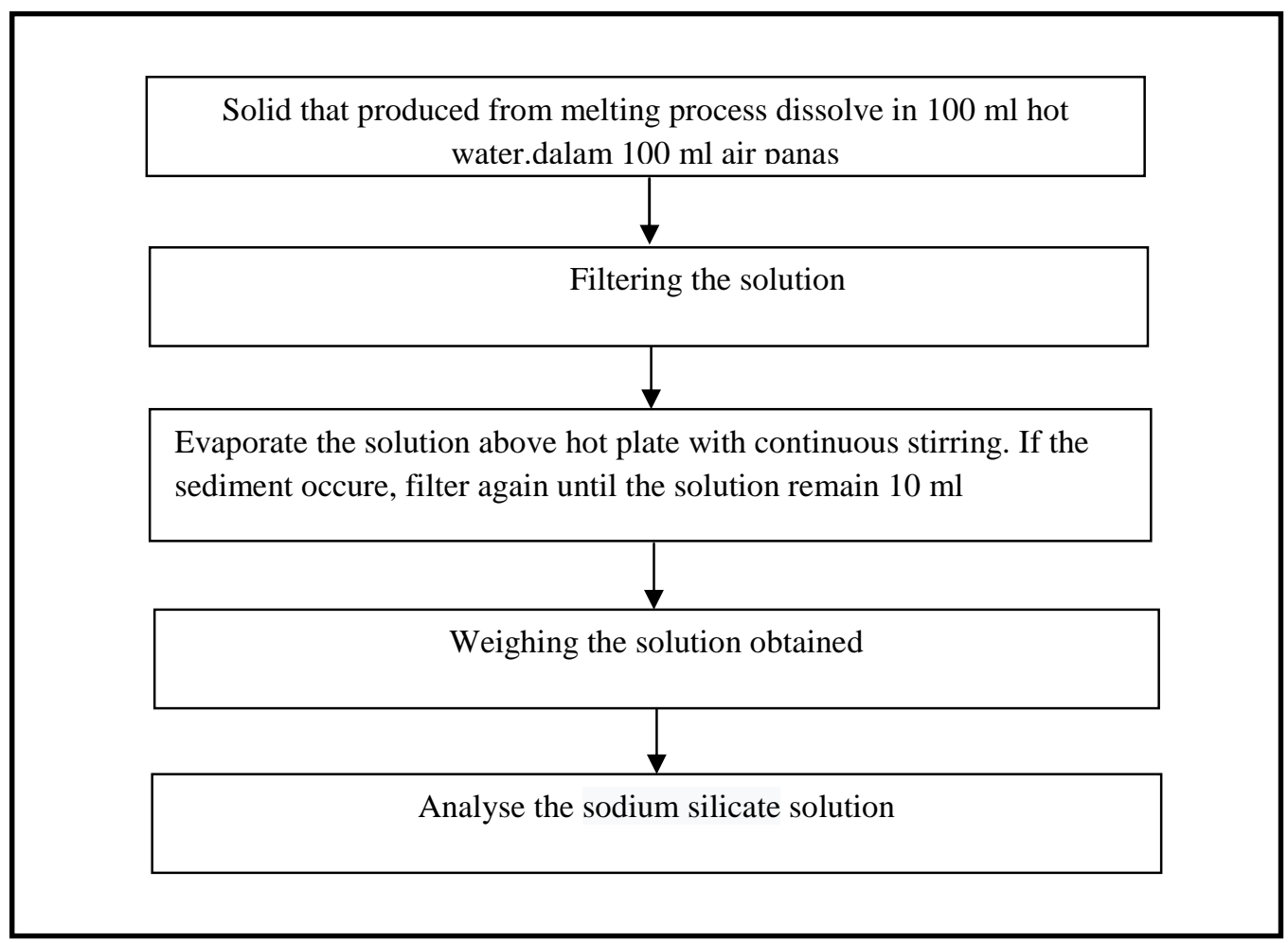

Fig 3. Acid Leaching Process Contonue

\section{RESULTS AND DISCUSSION}

Table 1. Rice Husk Ash Content

\begin{tabular}{lc}
\hline Indicators & \multicolumn{2}{l}{ Weight } \\
\hline $\mathrm{SiO}_{2}$ & 47.70 \\
$\mathrm{MgO}$ & 11.82 \\
$\mathrm{CaO}$ & 13.10 \\
$\mathrm{Fe}_{2} \mathrm{O}_{3}$ & 2.36 \\
$\mathrm{MnO}$ & 1.91 \\
$\mathrm{Al}_{2} \mathrm{O}_{3}$ & 22.90 \\
\hline
\end{tabular}




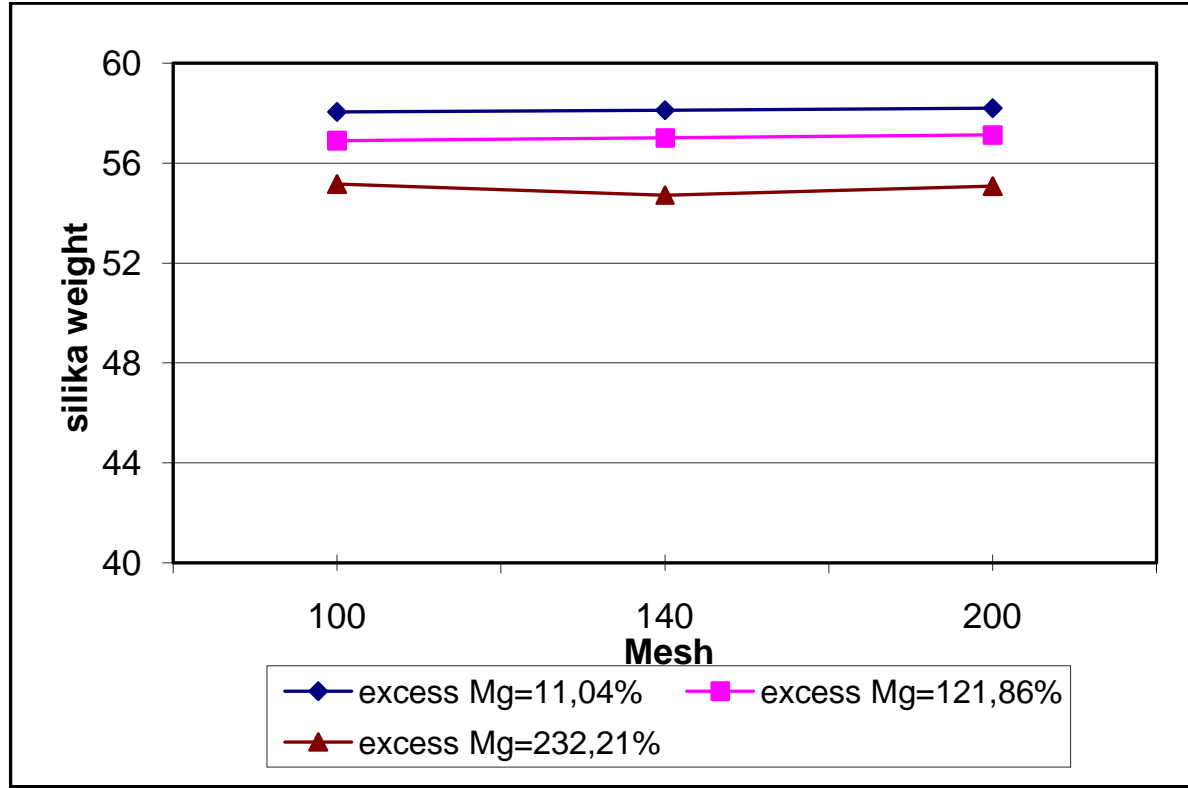

Figure 4. Effect of Magnesium addition to silica content after acid leaching

Figure 4 shown that magnesium addition influence the silica content. The silica content become maximum in ratio $\mathrm{Mg}$ : silica $=1: 1$. In these ratio, silica content become high and these ratio effective to reduce metal oxide as an impurities. But after the ratio increased, the silica content decreased. This matter indicate that the effective addition for calcium and magnesium to increase the silica content in rice husk ash is at the smallest ratio.
Because if the addition exceed the needed in their activity to reduce the metal oxide, they will become new impurities in the rice husk ash that will decrease the silica content. This matter caused by the addition of calcium and magnesium have very excessive, far through its equivalent point, so that there is a lot of reactan that do not react. These unreact reactan will cause a decline in silica content. 
Table 2. Yield of water glass for rice husk ash with Mg treatment

\begin{tabular}{|c|c|c|c|c|}
\hline Mesh & $\begin{array}{c}\text { Rasio } \\
{\mathrm{Mg}: \mathrm{SiO}_{2}}\end{array}$ & $\begin{array}{c}\text { Rasio } \\
\mathrm{Na}_{2} \mathrm{CO}_{3}: \mathrm{SiO}_{2}\end{array}$ & $\mathrm{SiO}_{2} / \mathrm{Na}_{2} \mathrm{O}$ & Yield \\
\hline \multirow{9}{*}{100} & \multirow{3}{*}{$1: 1$} & $1: 1$ & 1.0174 & 1.4855 \\
\hline & & $2: 1$ & 1.0234 & 1.1324 \\
\hline & & $4: 1$ & 1.0129 & 0.7698 \\
\hline & \multirow{3}{*}{$2: 1$} & $1: 1$ & 1.0078 & 1.5999 \\
\hline & & $2: 1$ & 1.0043 & 1.1313 \\
\hline & & $4: 1$ & 1.0042 & 0.7298 \\
\hline & \multirow{4}{*}{$3: 1$} & $1: 1$ & 1.0042 & 1.7850 \\
\hline & & $2: 1$ & 1.0042 & 1.3557 \\
\hline & & $4: 1$ & 1.0070 & 0.8080 \\
\hline \multirow{9}{*}{140} & & $1: 1$ & 1.0063 & 1.5064 \\
\hline & \multirow[t]{2}{*}{$1: 1$} & $2: 1$ & 1.0049 & 1.2032 \\
\hline & & $4: 1$ & 1.0021 & 0.7325 \\
\hline & \multirow{3}{*}{$2: 1$} & $1: 1$ & 1.0056 & 1.6584 \\
\hline & & $2: 1$ & 1.0056 & 1.1172 \\
\hline & & $4: 1$ & 1.0028 & 0.7333 \\
\hline & \multirow{3}{*}{$3: 1$} & $1: 1$ & 1.0028 & 1.6711 \\
\hline & & $2: 1$ & 1.0055 & 1.3015 \\
\hline & & $4: 1$ & 1.0056 & 0.8713 \\
\hline \multirow{9}{*}{200} & \multirow{3}{*}{$1: 1$} & $1: 1$ & 1.0084 & 1.4297 \\
\hline & & $2: 1$ & 1.0077 & 1.0870 \\
\hline & & $4: 1$ & 1.0049 & 0.7070 \\
\hline & \multirow{3}{*}{$2: 1$} & $1: 1$ & 1.0098 & 1.5773 \\
\hline & & $2: 1$ & 1.0042 & 1.1149 \\
\hline & & $4: 1$ & 1.0056 & 0.7401 \\
\hline & \multirow{3}{*}{$3: 1$} & $1: 1$ & 1.0084 & 1.6419 \\
\hline & & $2: 1$ & 1.0084 & 1.2762 \\
\hline & & $4: 1$ & 1.0063 & 0.8095 \\
\hline
\end{tabular}

Table 2 shown that particle size influence the increase of silica content in rice husk ash. Silica content will increase as much as the increase in their mesh. Increase in mesh means that decrease in particle size. But in the particle size 200 mesh there is decrease in silica content. This matter caused by losses in acid leaching and filtering process. In particle size 100 mesh, the silica content lower than particle size 140 mesh because in particle size 100 mesh the particle is big enough so in acid leaching process the surface contact is not maximum and the effectiveness of acid leaching is less perfect. So, the particle size 140 mesh give the maximum silica content.

Ratio sodium carbonate to silica also give big influence in water glass yield as shown in table 2 . In melting process, silica in rice husk ash will react with sodium carbonate. Silica as limiting reactan and sodium carbonate as excess reactan, this is the condition to make the reaction goes perfectly. In ratio sodium carbonate to silica in rice husk ash $1: 1$, found that sodium carbonate still become a limiting reactan and silica become excess reactan. This means that the reaction doesn't goes completely so the water glass yield not maximum. In ratio sodium carbonate to silica in rice husk ash $2: 1$, found that sodium carbonate has become an excess reactan $13,33 \%$. Also in ratio sodium carbonate to silica in rice husk ash $4: 1$, found that sodium carbonate has become an excess reactan $69,82 \%$. Sodium carbonate that become excess reactan give chance to silica in rice husk ash to react completely (100\%) so the water glass yield become maximum too.

As a standard, the difference between the neutral water glass and alkali water glass is in their $\mathrm{Na}_{2} \mathrm{O}$ to $\mathrm{SiO}_{2}$ ratio where in neutral water glass $\mathrm{Na}_{2} \mathrm{O}$ to $\mathrm{SiO}_{2}$ ratio is $1: 2,1$ and alkali water glass $\mathrm{Na}_{2} \mathrm{O}$ to $\mathrm{SiO}_{2}$ ratio is $1: 1,33$. In 


\section{TiBuana}

Journal of applied Industrial Engineering-University of PGRI Adi Buana

p-ISSN 2622-2027

$e$-ISSN 2622-2035

this experiment, as shown in table 2 and 3, $\mathrm{Na}_{2} \mathrm{O}$ to $\mathrm{SiO}_{2}$ ratio give various ratio \pm 1 . This shown that the water glass in this experiment is alkali water glass.

\section{CONCLUSIONS}

1. Rice husk ash can be used as an alternative material to make water glass because of its high silica content.

\section{REFERENCES}

1. Souza et al. "Rice Hull-Derived Silica : Application in Portland Cement and Mullite Whiskers". University of Sao Paulo. 2000.

2. Wittayakun, Jatuporn, "Silica Production From Rice Husk and Rice Husk Ash," Department of Chemical Engineering, Khon Kaen, 40002, Thailand, 2000.

3. Rodrigues, Marina. "Effect of Temperature and Particle Size on The Acid Leaching Process for Solar Grade Silicon Production". University of Paulista. 2000.

4. Kirk-Othmer, "Encyclopedia of Chemical Technology," $2^{\text {nd }}$ edition, 18, John Wiley and Son Inc, USA, 1969.

5. Pramana, Y. B. (2018). ANALYSIS OF LOSS WATER ON PIPE
2. Magnesium addition can increase silica content in rice husk ash. The mole ratio that effective to increase Ratio $\mathrm{Mg}: \mathrm{SiO}_{2}=1$ : 1 gives the highest silica content $58,20 \%$

3. Particle size of rice husk ash also influence the silica content. Rice husk hush with 120140 mesh $(0,124 \mathrm{~mm})$ gives the highest silica content. The silica content up to $58,12 \%$ weight in addition ratio $\mathrm{Mg}$ : Silika $1: 1$.

\section{DISTRIBUTION "NON REVENUE WATER (NRW)" NETWORK PDAM SURYA SEMBADA CITY OF SURABAYA WITH CAUSAL LOOP DIAGRAM (CLD). Tibuana , 24-33.}

6. Pramana, Y. B., Yakin, A., Putri, N. S., Huda, A. M. (2019). BIODIESEL FROM NYAMPLUNG (CALOPHYLLUM INOPHYLLUM) SEED OILWITH A TRANSESTERIFICATION PROCESS USING A CONTINOUS FLOW SYSTEM IN THE REACTOR. Tibuana, 36-39.

7. Waluyo, D. A., Pramana, Y. B. (2019). DESIGN "SANGRAI" TOOL FOR COFFE WITH STIRER FIN. Tibuana, 59. 